University of Nebraska - Lincoln

DigitalCommons@University of Nebraska - Lincoln

Publications, Agencies and Staff of the U.S.

Department of Commerce

U.S. Department of Commerce

1995

\title{
Dreissena polymorpha in the Saginaw Bay, Lake Huron Ecosystem: Overview and Perspective
}

\author{
Thomas F. Nalepa \\ National Oceanic and Atmospheric Administration, thomas.nalepa@noaa.gov \\ Gary L. Fahnenstiel \\ National Oceanic and Atmospheric Administration
}

Follow this and additional works at: https://digitalcommons.unl.edu/usdeptcommercepub

Part of the Environmental Sciences Commons

\footnotetext{
Nalepa, Thomas F. and Fahnenstiel, Gary L., "Dreissena polymorpha in the Saginaw Bay, Lake Huron Ecosystem: Overview and Perspective" (1995). Publications, Agencies and Staff of the U.S. Department of Commerce. 391.

https://digitalcommons.unl.edu/usdeptcommercepub/391

This Article is brought to you for free and open access by the U.S. Department of Commerce at DigitalCommons@University of Nebraska - Lincoln. It has been accepted for inclusion in Publications, Agencies and Staff of the U.S. Department of Commerce by an authorized administrator of DigitalCommons@University of Nebraska - Lincoln.
} 


\title{
Dreissena polymorpha in the Saginaw Bay, Lake Huron Ecosystem: Overview and Perspective
}

\author{
Thomas F. Nalepa ${ }^{1}$ and Gary L. Fahnenstiel ${ }^{2}$ \\ ${ }^{1}$ Great Lakes Environmental Research Laboratory \\ National Oceanic and Atmospheric Administration \\ 2205 Commonwealth Blvd. \\ Ann Arbor, Michigan 48105 \\ ${ }^{2}$ Lake Michigan Field Station \\ Great Lakes Environmental Research Laboratory \\ National Oceanic and Atmospheric Administration \\ 1431 Beach St. \\ Muskegon, Michigan 49441
}

After the zebra mussel, Dreissena polymorpha, was first discovered in Lake St. Clair in 1988 and rapidly spread throughout the Great Lakes, broad ecological changes became apparent in regions where this species was most abundant. Previous investigations documented dramatic increases in water clarity (Hebert et al. 1991, Marsden et al. 1993, Leach 1993), declines in chlorophyll and phytoplankton abundances (Leach 1993, Nicholls and Hopkins 1993, Holland 1993), and changes in benthic invertebrate communities (Griffiths 1993, Dermott et al. 1993, Stewart and Haynes 1994). These studies were conducted in various regions and defined impacts on a specific ecosystem component. Taken together, results indicate a major shift in energy flow patterns from the pelagic to the benthic region. Such a shift is so fundamental that every component of the food web from bacteria to fish would likely be affected either directly or indirectly. Thus, to truly understand the significance of shifts in energy flow patterns, impact assessments should be as holistic as possible within a given ecosystem. Despite the magnitude of observed impacts, however, establishing cause-effect relationships at the ecosystem-level is not an easy task. Not all changes occur at the same rate, and natural variation, along with man-induced influences such as nutrient abatement programs, confound interpretations of any mussel-induced impacts. For this reason, ecosystem- level impacts can best be examined, interpreted, and certainly modeled, by integrating studies of both ecosystem structure and function within a specific, well-defined region.

Soon after Dreissena was first discovered in the Great Lakes, we identified Saginaw Bay as an ideal location to assess ecosystem impacts. The bay had all the general characteristics defined by Officer et al. (1982) as potentially important in delineating impacts of a benthic filter-feeding population. First, the inner bay is shallow (mean depth $=5 \mathrm{~m}$ ) and well-mixed, maximizing the ratio of bottom area to water volume and minimizing vertical gradients. Second, the inner bay is a partially enclosed region of substantial size with a hydraulic retention time of about 120 days (entire bay 60 days; Bratzel et al. 1977); this minimizes the significance of hydraulic exchange as a confounding variable. Third, nutrient supplies are adequate to support a high phytoplankton population; values of primary production and phytoplankton biomass were among the highest recorded in the Great Lakes (Vollenweider et al. 1974).

In addition, other, more specific considerations led to the decision to focus our efforts in Saginaw Bay: 1) at the time, Dreissena was not yet established in the bay, thus baseline conditions immediately prior to the mussels' invasion could be documented; further, previous surveys of water 
quality parameters in 1974-80 (Smith et al. 1977, Bierman et al. 1984) could provide a longer-term perspective to assess potential changes; 2) the bay had extensive areas of hard bottom, along with ideal temperature and food regimes, and thus large populations of mussels were expected to develop; 3) there existed an important commerical and sport fishery that could be affected; 4) with a natural gradient between the eutrophic inner bay and the more oligotrophic outer bay, the bay provided an opportunity to assess impacts over a wide range of trophic conditions; and 5) the bay is an Area of Concern as designated by the International Joint Commission and the subject of remedial action by the State of Michigan. After a decade of little or no monitoring in the bay, initial surveys would provide information on the bay's response to continued efforts to improve water quality.

In 1990, we initiated a small study in Saginaw Bay in which a limited number of variables (chlorophyll, primary production, phytoplankton, zooplankton, and benthos) were measured three times a year at 13 sites. The study was greatly expanded beginning in 1991 when funds were appropriated by Congress as part of the Nonindigenous Aquatic Nuisance Prevention and Control Act. Because of the great interest in Saginaw Bay, other agencies (U.S. Environmental Protection Agency, Michigan Department of Natural Resources, Sea Grant) became participants as the study expanded to examine more variables over larger temporal and spatial scales.

Papers in this Special Section present results of studies conducted mainly during the early years of Dreissena's invasion into Saginaw Bay (1990-93). The papers summarize data collected in the bay over the long term (months, years), and also data derived from experimental manipulations over the short term (hours, days). The former document broad temporal and spatial changes in water quality parameters (Fahnenstiel et al. 1995a), primary production (Fahnenstiel et al. 1995b), nutrients (Johengen et al. 1995), and submersed macrophytes/ benthic algae (Skubinna et al. 1995, Lowe and Pillsbury 1995), while the latter determine impacts of Dreissena on planktonic bacteria (Cotner et al. 1995), protozoa (Lavrentyev et al. 1995), and nutrient dynamics (Gardner et al. 1995, Heath et al. 1995). Other papers examine rate processes to assess the relative importance of mussel filtration (Fanslow et al. 1995) and zooplankton grazing (Bridgeman et al. 1995) in effecting changes ob- served over the study period. Interpretations of mussel impacts are dependent upon estimates of population standing stocks, which were provided by Nalepa et al. (1995).

The papers contained herein illustrate the dramatic and immediate impact Dreissena can have on a given ecosystem. Changes in water quality parameters were apparent in Saginaw Bay soon after the inital population explosion of Dreissena in summer 1991. By fall 1991 and through 1992 and 1993, chlorophyll concentrations in the inner bay declined by $59 \%$, total phosphorus declined by $42 \%$, and water transparency increased by $60 \%$ (Fahnenstiel et al. 1995a). Similar declines were observed in particulate nutrients such as particulate organic carbon, particulate phosphorus, and particulate silica (Johengen et al. 1995). To put these changes into a long-term perspective, declines in chlorophyll immediately after the Dreissena infestation were similar to, or greater than, declines noted immediately after phosphorus control measures were implemented in the mid-1970s (Fahnenstiel et al. 1995a). Thus, measures of water quality in Saginaw Bay show three distinct phases over the past 20 years: pre-phosphorus control (1974-75), post-phosphorus control (1979-90), and post-Dreissena (1992-93). Trends in phosphorus loading into the bay between 1979 and 1992 were not evident and were, therefore, not a factor in the observed water quality changes.

Because of a decline in phytoplankton standing stocks (as measured by chlorophyll), phytoplankton production decreased by $38 \%$ in the inner bay after mussel colonization (Fahnenstiel et al. 1995b). On the other hand, primary production in the benthic region increased, as evidenced by an increase in the areal extent of submersed macrophytes (Skubinna et al. 1995), and an increase in benthic algal biomass and productivity (Lowe and Pillsbury 1995). Increased benthic productivity was most likely a result of increased light penetration to the bottom (Fahnenstiel et al. 1995b). When existing standing stocks and measures of phytoplankton growth rates, Dreissena filtration rates, and zooplankton grazing are compared, observed shifts in productivity can only be attributed to the filtering activities of the mussel population (Fahnenstiel et al. 1995b). Overall, it does not appear Dreissena altered the trophic state of the Saginaw Bay system, but rather altered the spatial partitioning of resources and productivity (Fahnenstiel et al. 1995a, b)

Because rate processes of most components of 
the planktonic food web (nutrients, bacteria, protozoa, phytoplankton) occur over very short time scales, studies to examine changes in these rates are useful in interpreting trends in standing stocks and composition of the plankton community over the long term. Also, interactions between lower food web components are potentially complex (see Fig. 1 in Gardner et al. 1995) and often best examined under controlled conditions. Results of short-term bottle and mesocosm experiments showed that Dreissena can not only affect food web components directly by selective removal, but also indirectly by nutrient excretion (Cotner et al. 1995, Gardner et al. 1995, Heath et al. 1995). For example, in mesocosm experiments, Dreissena decreased standing stocks of phytoplankton, but increased growth rates of phytoplankton that remained (Heath et al. 1995). Excretion of remineralized nutrients (phosphorus) by Dreissena stimulated phytoplankton growth in a phosphorus-limited system. Similar changes were observed in the inner bay over the long term; chlorophyll concentrations were lower in 1992 and 1993 compared to 1991 , but growth rates of phytoplankton increased (Fahnenstiel et al. 1995a; Fahnenstiel unpublished data). In the mesocosm experiments, soluble reactive phosphorus initially increased because of mussel excretion, but then declined with increased phytoplankton growth. Similarly, values of soluble reactive phosphorus in the inner bay declined after Dreissena became established (Johengen et al. 1995). Short-term experiments further indicated that Dreissena filtration and/or nutrient excretion can alter phytoplankton composition. Despite declines in other phytoplankton groups in treatments with Dreissena, biovolumes and abundances of cyanophytes were unchanged over the experimental period (Heath et al. 1995, Lavrentyev et al. 1995). Thus, Dreissena may increase the relative abundance of cyanophytes and even contribute to blooms. These results are provocative and contrast to the findings of others. For example, in a study of the effect of Dreissena on phytoplankton in Lake Erie, Nicholls and Hopkins (1993) reported Dreissena affected all phytoplankton groups equally, including cyanophytes. Certainly more research is needed on the possible role of Dreissena in causing changes in phytoplankton composition.

There are few studies in fresh water that document ecosystem-level changes resulting from the introduction of a benthic suspension feeder. In the tidal freshwater Potomac, the establishment of the asiatic clam, Corbicula fluminata, led to a 3-fold increase in water clarity, a 40-65\% decline in chlorophyll, and an increase in submersed aquatic macrophytes in a section of the river where clams were most abundant (Cohen et al. 1984, Phelps 1994). Clams theoretically filtered the river section in 3-4 days compared to 33 days for zooplankton. In 2 years of study in Saginaw Bay, Dreissena filtered the inner bay in 0.8 and 4 days (Fanslow et al. 1995) compared to a maximum of 17 and 37 days for zooplankton (Bridgeman et al. 1995). Thus, our findings in Saginaw Bay are remarkably similar to those in the Potomac. In the Potomac, the clam population declined dramatically 8 years after reaching a peak. Subsequently, water clarity declined, submersed aquatic vegetation declined, and cyanophyte blooms once again became evident (Phelps 1994).

Given findings in Saginaw Bay, the establishment of Dreissena has long-term implications when defining ecosystem response to management actions. For one, eutrophication models that link nutrient loadings and pelagic measures of water quality are no longer valid in areas with large populations of Dreissena. The Saginaw Bay ecosystem has been fundamentally altered, shifting from a system where productivity is focused in the pelagic region to a system where benthic productivity is also important. Previous eutrophication and water quality models were strictly based on a pelagic system, with phytoplankton the dominant primary producers and crustacean zooplankton the dominant herbivores (DiToro and Matystik 1980, Bierman et al. 1984). Simple re-paramaterization of existing mathematical models may not be adequate to describe the response of this altered system to management actions. For example, changes in nutrient loadings may now be more reflected in corresponding changes in metaphytonic and benthic algae, and not phytoplankton. Many metaphytonic and benthic algae belong to the order Zgynematales, an algal group that is extremely diverse and for which little information exists in the Great Lakes. Moreover, increases in primary production due to increased nutrient loadings may now be more reflected in first-order shifts in populations of benthic-dwelling decapods rather than crustacean zooplankton. The internal cycling of nutrient inputs also needs to be reconsidered. In Saginaw Bay, a phosphorus budget indicated standing stocks of Dreissena were a significant sink for phosphorus, accounting for 13$200 \%$ of the annual phosphorus pool in the water 
column in the inner bay, and a maximum of $56 \%$ of the total phosphorus load (Johengen et al. 1995). The long-term fate of phosphorus sedimented via feces and pseudofeces is still an unknown.

Future eutrophication and ecosystem models will likely be very different from past models, with new relationships and energy pathways identified. Assumptions will need to be validated with experimental data, and predictions will need to be calibrated and verified against long-term data sets. In addition, other management tools to understand and assess the state of water quality, fisheries, toxic contaminants, etc. will also need to be re-evaluated. For example, the abundance and diversity of benthic invertebrates have often been used as an indicator of water quality in the Great Lakes. With the establishment of large populations of Dreissena, we can no longer assume that changes in abundance and composition of the benthic community reflect changes in water quality. Dreissena has altered the abundance and composition of benthic invertebrates in Saginaw Bay (Nalepa unpublished data), but has not altered the bay's trophic state (Fahnenstiel et al. 1995b). Not only are shallow regions with large Dreissena populations impacted, but any system which receives a large supply of its chemical loading (nutrients, toxic contaminants, etc.) from a Dreissena-impacted region (such as tributaries, bays, nearshore zone) will likely also be impacted.

One of the key issues that needs to be resolved is the extent by which Dreissena changes the stability and predictability of the ecosystem. In the past, most changes in ecosystem components have permeated through the top (fisheries) or bottom (nutrients, toxic contaminants) of the food web. The introduction of a non-discriminate, benthic filterfeeder in the "middle" of the food web in the Great Lakes adds another controlling variable. In addition, not only does the mussel population create instability by altering normal energy pathways, but populations in turn readily respond to induced changes (Nalepa et al. 1995). Models of estuarine systems have clearly established suspension-feeders that form pseudofeces as the most important determinant of stability in the lower food web (Cloern 1982, Officer et al. 1982, Herman and Scholten 1990, Rodhouse and Roden 1987). In one carbonflow model, suspension feeders contributed to functional stability of the ecosystem by exerting continuous pressure on phytoplankton populations, but in so doing, greatly increased the vulnerability of the system to nutrient loadings (Herman and
Scholten 1990). When biomass of suspension feeders was at equilibrium, an increase in nutrient loading had little impact on phytoplankton biomass; however, with the same nutrient increase, a small decrease in suspension-feeder biomass led to drastic increases in phytoplankton biomass. In Saginaw Bay, a 10-fold decline in Dreissena biomass between 1992 and 1993 had little impact on water quality parameters (Fahnenstiel et al. 1995a). Yet even with this biomass decline in 1993, the population could still theoretically filter the entire volume of the inner bay in 4 days (Fanslow et al. 1995). Given Dreissena standing stocks in Saginaw Bay have fluctuated and may not yet be at equilibrium (Nalepa et al. 1995), relationships between Dreissena populations and water quality parameters may not be fully understood until more yearly data are available.

Hopefully, results from this Special Section will be useful for assessing the Great Lakes system in the post-Dreissena era. Monitoring of water quality parameters, Dreissena standing stocks, and food web components in Saginaw Bay has continued through 1995. In future papers, we will focus on trends in the abundance and composition of phytoplankton, zooplankton, and benthos. Other important topics being examined are the role of Dreissena in sediment resuspension, and interactions between Dreissena filtration/rejection activities and cyanophyte blooms.

\section{ACKNOWLEDGMENTS}

We thank Al Beeton and Dave Reid for their support and encouragement during the project, particularly during the early years. We also thank Mike McCormick for his technical assistance and thought-provoking ideas, and Cathy Darnell for her editorial assistance. The constructive comments and suggestions of all reviewers greatly increased the quality of the manuscripts and their efforts are much appreciated. Also, we thank all the authors for their prompt responses during the revision process. This is GLERL Contribution Number 970.

\section{REFERENCES}

Bierman, V. J., Dolan, D. M., and Kasprzyk, R. 1984. Retrospective analysis of the response of Saginaw Bay, Lake Huron, to reductions in phosphorus loadings. Environ. Sci. Technol. 18:23-31.

Bratzel, M. P., Thompson, M. E., and Bowden, R. J. (eds.) . 1977. The Water of Lake Huron and Lake 
Superior, Vol. II (Part A). Lake Huron, Georgian Bay, and the North Channel. Report to the International Joint Commission by the Upper Great Lakes Reference Group, Windsor, Ontario.

Bridgeman, T. B., Fahnenstiel, G. L., Lang, G. A., and Nalepa, T. F. 1995. The relative importance of zooplankton grazing during the zebra mussel (Dreissena polymorpha) colonization of Saginaw Bay, Lake Huron. J. Great Lakes Res. 21:567-573.

Cloern, J.E. 1982. Does the benthos control phytoplankton biomass in South San Francisco Bay? Mar. Ecol. Prog. Ser. 9:191-202.

Cohen, R.R.H., Dresler, P.V., Philips, E.J.P., and Cory, R.L. 1984. The effect of the Asiatic clam, Corbicula fluminea, on phytoplankton of the Potomac River, Maryland. Limnol. Oceanogr. 29: 170-180.

Cotner, J. B., Gardner, W. S., Johnson, J. R., Sada, R. H., Cavaletto, J. F. , and Heath, R. T. 1995. Effects of zebra mussels (Dreissena polymorpha) on bacterioplankton: evidence for both size-selective consumption and growth stimulation. J. Great Lakes Res. 21:517-528.

Dermott, R., Mitchell, J., Murray, I., and Fear, E. 1993. Biomass and production of zebra mussels (Dreissena polymorpha) in shallow waters of Northeastern Lake Erie. In Zebra Mussels: Biology, Impacts, and Control, eds. T. F. Nalepa and D. W. Schloesser, pp. 399-413. Boca Raton, FL: Lewis Publishers/CRC Press.

DiToro, D. M., and W. F. Matystik. 1980. Mathematical models of water quality in large lakes. Part 1: Lake Huron and Saginaw Bay. EPA-600/3-80-056.

Fahnenstiel, G. L., Lang, G. A., Nalepa, T. F., and Johengen, T. H. 1995a. Effects of zebra mussel (Dreissena polymorpha) colonization on water quality parameters in Saginaw Bay, Lake Huron. J. Great Lakes Res. 21:435-448.

Bridgeman, T. B., Lang, G. A., McCormick, M. J., and Nalepa, T. F. 1995b. Phytoplankton productivity in Saginaw Bay, Lake Huron: effects of zebra mussel (Dreissena polymorpha) colonization. $J$. Great Lakes Res. 21:465-475.

Fanslow, D. L., Nalepa, T. F., and Lang, G. A. 1995. Filtration rates of zebra mussels (Dreissena polymorpha) on natural seston from Saginaw Bay, Lake Huron. $J$. Great Lakes Res. 21:489-500.

Gardner, W. S., Cavaletto, J. F., Johengen, T. H., Johnson, J. R., Heath, R. T., and Cotner, J. B. 1995. Effects of the zebra mussel (Dreissena polymorpha) on nitrogen dynamics in Saginaw Bay, Lake Huron. $J$. Great Lakes Res. 21:529-544.

Griffiths, R.W. 1993. Effects of zebra mussels (Dreissena polymorpha) on the benthic fauna of Lake St. Clair. In Zebra Mussels: Biology, Impacts, and Control, eds. T. F. Nalepa and D. W. Schloesser, pp. 415-437. Boca Raton, FL: Lewis Publishers/CRC Press.
Heath, R. T., Fahnenstiel, G. L., Gardner, W. S., Cavaletto, J. F., and Hwang, S. J. 1995. Ecosystem-level effects of zebra mussels (Dreissena polymorpha): an enclosure experiment in Saginaw Bay, Lake Huron. $J$. Great Lakes Res. 21:501-516.

Hebert, P. D. N., Wilson, C. C., Murdoch, M. H., and Lazar, R. 1991. Demography and ecological impacts of the invading mollusc, Dreissena polymorpha. Can. J. Zool. 69:405-409.

Herman, P.M.J., and Scholten, H. 1990. Can suspensionfeeders stabilise estuarine ecosystems? In Trophic Relationships in the Marine Environment, eds. M. Barnes and R.N. Gibson, pp. 104-116. Aberdeen, UK: Aberdeen University Press.

Holland, R. E. 1993. Changes in planktonic diatoms and water transparency in Hatchery Bay, Bass Island area, Western Lake Erie since the establishment of the zebra mussel. J. Great Lakes Res. 19:617-624.

Johengen, T. H., Nalepa, T. F., Fahnenstiel, G. L., and Goudy, G. 1995. Nutrient changes in Saginaw Bay, Lake Huron, after the establishment of the zebra mussel (Dreissena polymorpha). J. Great Lakes Res. 21:449-464.

Lavrentyev, P.J., Gardner, W.S., Cavaletto, J.F., and Beaver, J.R. 1995. Effects of the zebra mussel (Dreissena polymorpha Pallas) on protozoa and phytoplankton from Saginaw Bay, Lake Huron. J. Great Lakes Res. 21:545-557.

Leach, J. H. 1993. Impacts of the zebra mussel (Dreissena polymorpha) on water quality and fish spawning reefs in western Lake Erie. In Zebra Mussels: Biology, Impacts, and Control, eds. T. F. Nalepa and D. W. Schloesser, pp. 381-397. Boca Raton, FL : Lewis Publishers/CRC Press.

Lowe, R.L., and Pillsbury, R.W. 1995. Shifts in benthic algal community structure and function following the appearance of zebra mussels (Dreissena polymorpha) in Saginaw Bay, Lake Huron. J.Great Lakes Res. 21:558-566.

Marsden, J. E., Trudeau, N., and Keniry, T. 1993. Zebra mussel study of Lake Michigan. Aquatic Ecology Technical Report 93/14, Illinois Natural History Survey.

Nalepa, T. F., Wojcik, J. A., Fanslow, D. L., and Lang, G. A. 1995. Initial colonization of the zebra mussel (Dreissena polymorpha) in Saginaw Bay, Lake Huron: population recruitment, density and size structure. J. Great Lakes Res. 21:417-434.

Nicholls, K. H., and Hopkins, G. J. 1993. Recent changes in Lake Erie (north shore) phytoplankton: cumulative impacts of phosphorus loading reduction and the zebra mussel introduction. J. Great Lakes Res. 19:637-647.

Officer, C. B., Smayda, T. J., and Mann, R. 1982. Benthic filter feeding: a natural eutrophication control. Mar. Ecol. Prog. Ser. 9:203-210. 
Phelps, H.L. 1994. The Asiatic clam (Corbicula fluminea) invasion and system-level ecological change in the Potomac River Estuary near Washington, D.C. Estuaries 17:614-621.

Rodhouse, P.G., and Roden, C.M. 1987. Carbon budget for a coastal inlet in relation to intensive cultivation of suspension-feeding bivalve molluscs. Mar. Ecol. Prog. Ser. 36:225-236.

Skubinna, J. P., Coon, T. G., and Batterson, T. R. 1995. Increased abundance and depth of submersed macrophytes in response to decreased turbidity in Saginaw Bay, Lake Huron. J. Great Lakes Res. 21: 476-488.
Smith, V.E., Lee, K.W., Filkins, J.C., Hartwell, K.W., Rygwelski, K.R., and Townsend, J.M. 1977. Survey of chemical factors in Saginaw Bay (Lake Huron). EPA600/3-77-125, U.S. Environmental Protection Agency, Duluth, Minnesota.

Stewart, T.W., and Haynes, J.M. 1994. Benthic macroinvertebrate communities of southwestern Lake Ontario following invasion of Dreissena. J. Great Lakes Res. 20:479-493.

Vollenweider, R. A., Munawar, M., and Stadelman, P. 1974. A comparative review of phytoplankton and primary production in the Laurentian Great Lakes. $J$. Fish. Res. Board Can. 31:739-762. 